\title{
Solubilization and Partial Purification of Dihydroxyacetone-Phosphate Acyltransferase from Guinea Pig Liver ${ }^{1}$
}

\author{
CHRISTOPHER L. JONES ${ }^{2}$ AND AMIYA K. HAJRA ${ }^{3}$
}

Neuroscience Laboratory, Mental Health Research Institute, and Department of Biological Chemistry, University of Michigan, Ann Arbor, Michigan 48109

Received February 22, 1983, and in revised form April 25, 1983

Dihydroxyacetone-phosphate:acyl coenzyme A acyltransferase (EC 2.3.1.42) was solubilized and partially purified from guinea pig liver crude peroxisomal fraction. The peroxisomal membrane was isolated after osmotic shock treatment and the bound dihydroxyacetone-phosphate acyltransferase was solubilized by treatment with a mixture of $\mathrm{KCl}-$ sodium cholate. The solubilized enzyme was partially purified by ammonium sulfate fractionation followed by Sepharose $6 \mathrm{~B}$ gel filtration. The enzyme was purified 1200 -fold relative to the guinea pig liver homogenate and 80 - to 100 -fold from the crude peroxisomal fraction, with an overall yield of $25-30 \%$ from peroxisomes. The partially purified enzyme was stimulated two- to fourfold by Asolectin (a soybean phospholipid preparation), and also by individual classes of phospholipid such as phosphatidylcholine and phosphatidylglycerol. The kinetic properties of the enzyme showed that in the absence of Asolectin there was a discontinuity in the reciprocal plot indicating two different apparent $K_{m}$ values $(0.1$ and $0.5 \mathrm{~mm})$ for dihydroxyacetone phosphate. The $V_{\max }$ was $333 \mathrm{nmol} / \mathrm{min} / \mathrm{mg}$ protein. In the presence of Asolectin the reciprocal plot was linear, with a $K_{m}=0.1 \mathrm{mM}$ and no change in $V_{\max }$. The enzyme catalyzed both an exchange of acyl groups between dihydroxyacetone phosphate and palmitoyl dihydroxyacetone phosphate in the presence of $\mathrm{CoA}$ and the formation of palmitoyl $\left[{ }^{3} \mathrm{H}\right]$ coenzyme $A$ from palmitoyl dihydroxyacetone phosphate and $\left[{ }^{3} \mathrm{H}\right]$ coenzyme $\mathrm{A}$, indicating that the reaction is reversible. The partially purified enzyme preparation had negligible glycerol-3-phosphate acyltransferase (EC 2.3.1.15) activity.

Acyl $\mathrm{DHAP}^{4}$ has been shown to be an intermediate for the biosynthesis of glycerolipids and glycerol ether lipids (1-4). The enzyme, DHAP acyltransferase (EC 2.3.1.42), is present as a membrane-bound form in different subcellular fractions of all mammalian tissues (5-11). Conflicting results have been reported regarding the

\footnotetext{
${ }^{1}$ This study was supported by the National Institutes of Health Grant NS 08841 .

${ }^{2}$ Present address: Department of Microbiology, University of Pittsburgh, Pittsburgh, Pennsylvania 15261.

${ }^{3}$ To whom all correspondence should be addressed.

4 Abbreviations used: DHAP, dihydroxyacetone phosphate; G-3-P, sn-glycerol-3-phosphate.
}

subcellular distribution and properties of this acyltransferase (5-14). Schlossman and Bell $(8,15)$ confirmed the results of Hajra (5) that liver microsomal DHAP acyllransferase is competitively inhibited by $\mathrm{G}-3-\mathrm{P}$, and these workers have further reported that in terms of $\mathrm{pH}$ optimum, thermolability and inhibition by thiol blocking agents the properties of these two acyltransferases are identical. On this basis, it was concluded that the same microsomal enzyme is probably catalyzing both the acylation reactions $(8,15)$. In contrast, Jones and Hajra (14) have shown that the major fraction (>95\%) of liver DHAP acyltransferase is present in peroxisomes, and its properties are quite different from 
that of the G-3-P acyltransferase present in the same fraction. These results raised the possibility that in liver there are present at least two acyltransferases that catalyze the acylation of DHAP, one specific (peroxisomal) using only DHAP as the substrate and the other nonspecific (in $\mathrm{mi}$ crosomes) which may use both DHAP and G-3-P as substrates. ${ }^{5}$ However, because of cross-contamination of one subcellular fraction with other, the catalytic activities of these two acyltransferases have not yet been separated from each other (14).

The reaction catalyzed by DHAP acyltransferase is postulated to be freely reversible (16) so that acyl $\mathrm{CoA}$ is formed from acyl DHAP and CoA, indicating that the $\mathrm{O}$-acyl bond of acyl DHAP has a higher free energy of hydrolysis than the corresponding $\mathrm{O}$-acyl bond in glycerolipids. However, the formation of acyl CoA from acyl DHAP and CoA could not be shown directly with the membrane-bound enzyme because of the presence of other acyltransferases and acyl CoA hydrolase in the same particulate preparation.

To resolve the above questions, i.e., the specificity of DHAP acyltransferase and the reversibility of the reaction, the enzyme was solubilized and partially purified from guinea pig liver peroxisomal fraction, and the properties were studied with respect to the above parameters. The kinetic and other properties of this solubilized acyltransferase, including its stimulation by phospholipids, were also studied. The results are reported here.

\section{EXPERIMENTAL PROCEDURES}

Materials. $N$-Ethylmaleimide, $p$-chloromercuriphenyl sulfonic acid, iodoacetamide, phosphatidylethanolamine, phosphatidylserine, phosphatidylinositol, phosphatidylglycerol, phosphatidylcholine, phosphatidic acid, and palmitoyl CoA were from Sigma Chemical Company (St. Louis, Mo.). [G- $\left.{ }^{3} \mathrm{H}\right] \mathrm{CoA}$ was obtained from New England Nuclear (Boston,

\footnotetext{
${ }^{5}$ Results from this laboratory indicate that the properties of the microsomal DHAP acyltransferase and G-3-P acyltransferase are also different (A. K. Hajra, N. Datta, and M. A. S. Salem, Fed. Proc 42, 1864).
}

Mass.). Stearoyl CoA and oleoyl CoA were purchased from P-L Biochemical (Milwaukee, Wisc.). Asolectin, a soybean phospholipid concentrate, was from Associated Concentrates (Woodside, N. Y.). Filters for ultrafiltration were bought from Amicon Corporation (Lexington, Mass.). Sepharose 6B and $\mathrm{CNBr}$-activated Sepharose 4B and DEAE-Sephacel were purchased from Pharmacia (Piscataway, N. J.). Palmitoyl DHAP was chemically synthesized from 1-palmitoyl-3diazoacetone as described by Hajra and Agranoff (17). Linoleyl (18:2), arachidonoyl (20:4), docosatetraenoyl (22:4), and docosahexaenoyl (22:6) CoA's were chemically synthesized by condensing $\mathrm{CoA}$ with the corresponding acyl chloride (18). Other materials were the same as described previously (14).

Methods. The assay of DHAP acyltransferase was done by measuring the formation of [ $\left.{ }^{32} \mathrm{P}\right]$ lipid from $\mathrm{DHA}^{32} \mathrm{P}$ and palmitoyl CoA as described by Jones and Hajra (14). When a phospholipid dispersion of Asolectin was included in the incubation mixture, 1.5-2 $\mu \mathrm{mol}$ of total lipid phosphorus, unless otherwise specified, were added. An Asolectin dispersion was prepared by sonicating the lipid in dilute Tris- $\mathrm{HCl}$ buffer (pH 7.4) and then centrifuging as described by Monroy et al (19). Dispersions of individual phospholipids (5$7 \mathrm{mg} / \mathrm{ml}$ ) were made by drying down the phospholipid solution in chloroform under a stream of nitrogen and then dispersing the lipids in $1 \%$ sodium cholate by sonicating for $5 \mathrm{~min}$ in a cylindrical ultrasonic bath (Laboratory Supplies Co., Hicksville, N. Y.). Organic phosphates were determined by the method of Ames and Dubin (20). Protein was measured by a modification of the method of Lowry (21) as described by Bensadoun and Weinstein (22). Polyacrylamide gels $(7.0 \%)$ with and without sodium dodecyl sulfate were prepared and the electrophoresis of different fractions was run as described by Fairbanks et al. (23). The protein bands were localized by staining with Coomassie brilliant blue R-250. Other methods were the same as described previously $(10,14,24)$.

Enzyme purification. All the operations were done at $4^{\circ} \mathrm{C}$. Crude peroxisomes (450-650 $\mathrm{mg}$ protein) were prepared from guinea pig liver ( 60 to $90 \mathrm{~g}$ wet $\mathrm{wt}$ ) by differential centrifugation of the homogenate (33,000-250,000g-min residue) according to de Duve et al. $(14,25)$. The peroxisomes were suspended $(3.25$ $\mathrm{mg}$ protein $/ \mathrm{ml}$ ) in a hypotonic pyrophosphate buffer pH 9.0,10 mM) for $30 \mathrm{~min}$ at $0^{\circ} \mathrm{C}$, and then centrifuged at $100,000 \mathrm{~g}$ for $30 \mathrm{~min}$. The sediment contained most (90-95\%) of the DHAP acyltransferase, while $60-70 \%$ of the protein remained in the supernatant. The membrane-bound enzyme was then solubilized by suspending the residue $(1-1.2 \mathrm{mg}$ protein $/ \mathrm{ml}$ ) in a mixture containing sodium cholate $(0.2 \%$ final concentration), $\mathrm{KCl}(1 \mathrm{M})$, dithiothreitol (1 $\mathrm{mM})$, and Tris-

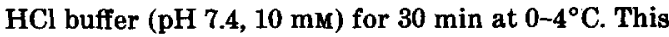
mixture was centrifuged at $100,000 g$ for $60 \mathrm{~min}$, and the soluble enzyme present in the supernatant was 
concentrated (15- to 20-fold) (approximately $10 \mathrm{mg}$ protein $/ \mathrm{ml}$ ) by ultrafiltration using an Amicon XM50 filter. The concentrated enzyme preparation (10$15 \mathrm{ml}$ ) was then fractionated by the stepwise addition of a saturated ammonium sulfate solution ( $\mathrm{pH} 7.0)$ at $0-4^{\circ} \mathrm{C}$. The fraction precipitating at $20-35 \%$ ammonium sulfate saturation was collected by centrifugation $(10,000 \mathrm{~g}, 10 \mathrm{~min})$ dissolved in $2 \mathrm{ml}$ Tris- $\mathrm{HCl}$ buffer (10 mM, pH 7.4) containing $\mathrm{KCl}(1 \mathrm{M})$ and dithiothreitol (1 $\mathrm{mM})$ and was then applied to a Sepharose $6 \mathrm{~B}$ column $(125 \times 1.3 \mathrm{~cm})$. The column was eluted with the same buffer mixture, and 5-ml fractions were collected. The enzyme activity and protein content of each fraction were determined. The fractions containing the main enzyme peak (see Fig. 1A) were pooled together and concentrated by ultrafiltration (Amicon XM-50 filter) to a final protein concentration of $0.5-1.0 \mathrm{mg} / \mathrm{ml}$. The concentrated enzyme was stored at $2-4^{\circ} \mathrm{C}$. A loss of $30-50 \%$ of the stored enzyme activity was observed after 1 month.

\section{RESULTS}

\section{Solubilization and Purification of the Enzyme}

Peroxisomal DHAP acyltransferase remained with the membrane fraction after the soluble enzymes were liberated by osmotic shock in dilute pyrophosphate buffer. Previously, it has been shown that the membrane-bound acyltransferase is solu- bilized by a number of detergents (14). Optimal solubilization was obtained by using a mixture of sodium cholate- $\mathrm{KCl}$ solution when most of the DHAP acyltransferase remained unsedimented after centrifugation for $100,000 \mathrm{~g}$ for $60 \mathrm{~min}$. Extractions of the enzyme with sodium cholate at the concentration of $10 \mathrm{mg} / \mathrm{ml}$ or more were most complete, but recovery of soluble enzyme was maximal at $2 \mathrm{mg} / \mathrm{ml}$ cholate. At higher cholate concentrations there was significant inhibition of DHAP acyltransferase. Using $\mathrm{KCl}(1 \mathrm{M})$ and cholate $(2 \mathrm{mg} /$ $\mathrm{ml}$ ), recovery of soluble enzyme was $200 \%$ relative to intact peroxisomes (Table I). This stimulation of activity was expected since a portion of the DHAP acyltransferase in peroxisomes was shown to be latent (14).

By ammonium sulfate fractionation, most of the enzyme (55-60\%) was precipitated out between 20 and $35 \%$ saturation with an enrichment of 2.2-fold. A portion of the activity (30-35\% of the total) was precipitated out between 35 and $50 \%$ saturation but with very little (1.2-fold) enrichment of activity. Some (5-10\%) DHAP acyltransferase precipitated at ammonium sulfate concentrations below $20 \%$, but this

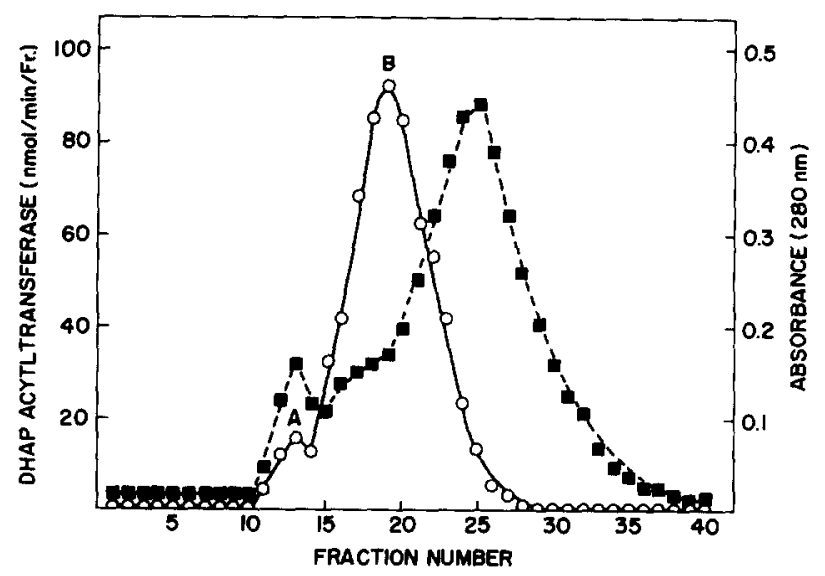

FIG. 1. Sepharose 6B chromatography of DHAP acyltransferase. Enzyme purified through ammonium sulfate fractionation as described under Experimental Procedures was applied to a Sepharose $6 \mathrm{~B}$ column $(125 \times 1.3 \mathrm{~cm})$. The column was equilibrated and eluted with a solution of $\mathrm{KCl}(1 \mathrm{M})$, dithiothreitol (1 mM), and Tris- $\mathrm{HCl}(10 \mathrm{mM}, \mathrm{pH} 7.4)$. An aliquot of each fraction $(5 \mathrm{ml})$ was assayed for enzyme activity $(O)$, and the absorbance of each fraction at $280 \mathrm{~nm}(\square)$ as a measure of protein content, was determined. Fractions No. 11 to 14 are combined and designated as "peak A" fraction and fractions No. 15 to 22 are combined for pooled peak $B$ fraction. 
TABLE I

Purification of DHaP acrltransferase from Guinea Pig Liver

\begin{tabular}{|c|c|c|c|c|c|c|c|}
\hline \multirow[b]{2}{*}{ Fraction } & \multicolumn{2}{|c|}{ Total activity (nmol/min) } & \multicolumn{2}{|c|}{$\begin{array}{c}\text { Specific activity } \\
\text { (nmol/min/mg protein) }\end{array}$} & \multicolumn{2}{|c|}{ Purification factor } & \multirow[b]{2}{*}{$\begin{array}{c}\text { Total } \\
\text { protein } \\
(\mathbf{m g})\end{array}$} \\
\hline & $\begin{array}{c}\text { DHAP } \\
\text { Acyl- } \\
\text { transferase }\end{array}$ & $\begin{array}{l}\text { GP Acyl- } \\
\text { transferase }\end{array}$ & $\begin{array}{c}\text { DHAP } \\
\text { Acyl- } \\
\text { transferase }\end{array}$ & $\begin{array}{l}\text { GP Acyl- } \\
\text { transferase }\end{array}$ & $\begin{array}{c}\text { DHAP } \\
\text { Acyl- } \\
\text { transferase }\end{array}$ & $\begin{array}{l}\text { GP Acyl- } \\
\text { transferase }\end{array}$ & \\
\hline Homogenate & $\begin{array}{c}2340 \\
(2650)\end{array}$ & 10,500 & $\begin{array}{c}0.15 \\
(0.17)\end{array}$ & 0.66 & $\begin{array}{c}1 \\
(1)\end{array}$ & 1 & 16,000 \\
\hline Peroxisomes & $\begin{array}{c}1100 \\
(1190)\end{array}$ & 670 & $\begin{array}{c}2.0 \\
(2.1)\end{array}$ & 1.20 & $\begin{array}{c}13 \\
(12)\end{array}$ & 1.8 & 560 \\
\hline Osmotic shock & $\begin{array}{c}1860 \\
(2230)\end{array}$ & 200 & $\begin{array}{c}9.1 \\
(10.9)\end{array}$ & 0.97 & $\begin{array}{c}60 \\
(64)\end{array}$ & 1.5 & 205 \\
\hline $\begin{array}{l}\text { KCl-cholate } \\
\text { solubilization }\end{array}$ & $\begin{array}{c}3620 \\
(4180)\end{array}$ & 30 & $\begin{array}{c}28 \\
(33)\end{array}$ & 0.24 & $\begin{array}{c}189 \\
(193)\end{array}$ & 0.36 & 127 \\
\hline Ultrafiltration & $\begin{array}{c}2680 \\
(4160)\end{array}$ & 29 & $\begin{array}{c}22 \\
(34)\end{array}$ & 0.24 & $\begin{array}{c}147 \\
(201)\end{array}$ & 0.36 & 122 \\
\hline $\begin{array}{r}\left(\mathrm{NH}_{4}\right)_{2} \mathrm{SO}_{4} 20- \\
35 \% \text { fraction }\end{array}$ & $\begin{array}{c}1100 \\
(1440)\end{array}$ & 5 & $\begin{array}{c}58 \\
(76)\end{array}$ & 0.11 & $\begin{array}{c}381 \\
(441)\end{array}$ & 0.17 & 19 \\
\hline $\begin{array}{r}\text { Sepharose 6B } \\
\text { pool Peak B }\end{array}$ & $\begin{array}{c}340 \\
(680)\end{array}$ & 0.4 & $\begin{array}{c}106 \\
(212)\end{array}$ & 0.13 & $\begin{array}{r}725 \\
(1250)\end{array}$ & 0.20 & 3.2 \\
\hline
\end{tabular}

Note. Peroxisomes were prepared by differential centrifugation from guinea pig liver homogenate (10\% in $0.25 \mathrm{~m}$ sucrose) as described by de Duve et al. (25). DHAP acyltransferase was purified from peroxisomes as described in the text (see Experimental Procedures). At each stage of purification DHAP acyltransferase and glycerol-3-P acyltransferase activity were measured in the absence of Asolectin. In addition, DHAP acyltransferase activity was measured in the presence of Asolectin (numbers in parentheses).

material was found to be insoluble and consisted mostly of membrane fragments.

DHAP acyltransferase was further purified by Sepharose $6 \mathrm{~B}$ chromatography in the presence of dithiothreitol and $1 \mathrm{M} \mathrm{KCl}$. Dithiothreitol was necessary to preserve the DHAP acyltransferase activity. $\mathrm{KCl}$ was necessary to keep the enzyme in soluble form since, in the absence of $\mathrm{KCl}$, almost all of the DHAP acyltransferase activity came out as a large protein peak in the void volume. In the presence of $\mathrm{KCl}$, DHAP acyltransferase was eluted as two peaks of activity (Figs. 1A and B). Peak A, the void volume peak, contained less than $10 \%$ of the recovered DHAP acyltransferase activity while peak $B$ contained the rest of the activity. The total recovery of enzyme activity from the $6 \mathrm{~B}$ column was $40-$ $60 \%$. Peak A enzyme was found to be pres- ent in large aggregates, probably still bound to the membrane fragments, and was not truly soluble. Peak B enzyme, although of large size $K_{\mathrm{av}}=0.34$; apparent $M_{\mathrm{r}} \simeq 3 \times 10^{5}$ ) represented the soluble form of the enzyme. When the material in peak B was concentrated and rechromatographed on the Sepharose column, only one peak corresponding to that of the original peak B $\left(K_{\text {av }}=0.34\right)$, came off the column indicating that, under the experimental conditions used, peak B was not converted back to peak A. Peak B enzyme was used for further studies.

A number of other purification procedures were tried with little success. The enzyme (peak B from Sepharose 6B column) was found to bind to a DEAE cellulose (DEAE-Sephacel) column at pH 7.4 and could be eluted as a single peak with 
$0.15 \mathrm{M} \mathrm{NaCl}$. But the recovery of enzyme activity (with Asolectin) was very poor (5$15 \%)$, and little purification (1.2- to 1.5fold) was achieved. Also, the enzyme recovered from the DEAE-cellulose column was very unstable with $90 \%$ of its activity lost on overnight storage at $2-4^{\circ} \mathrm{C}$ or by freezing and thawing; therefore this method was not routinely used for purification purposes.

Other attempts to further purify the enzyme included hydrophobic chromatography, affinity chromatography, and isoelectric focusing. When applied to a hydrophobic gel prepared according to Shaltiel (26), DHAP acyltransferase could not be eluted from columns with six or more carbons per chain, while with hydrophobic columns containing two or four carbons, no purification was achieved. The enzyme did not bind to a CoA affinity column which was prepared as described by Chibata $e t$ al. (27). Very poor recovery of enzyme activity was obtained by isoelectric focusing because of protein precipitation and consequent enzyme denaturation.

The methods described above were combined to partially purify DHAP acyltransferase from guinea pig liver, and the results are in Table I. Overall purification from the liver homogenate was over 1200-fold with a recovery of $10-15 \%$ when DHAP acyltransferase was assayed with Asolectin. From crude peroxisomes the purification was 100 -fold and the recovery $25-$ $30 \%$. Upon polyacrylamide gel $(5 \%)$ electrophoresis (no SDS) the enzyme activity was found only on the top $0.5-\mathrm{cm}$ section of the gel indicating that the purified enzyme did not enter this high-porosity gel. On sodium dodecyl sulfate-polyacrylamide gel $(7 \%)$ electrophoresis two closely spaced major bands $\left(M_{\mathrm{r}}=54,000\right.$ and 56,000$)$ were enriched during the purification of enzyme (Fig. 2). A number of other minor bands were also present in the final enzyme preparation (Fig. 2).

The purification of a closely related enzyme, G-3-P acyltransferase, was monitored for comparison purposes. From the results in Table $I$ it is apparent that these

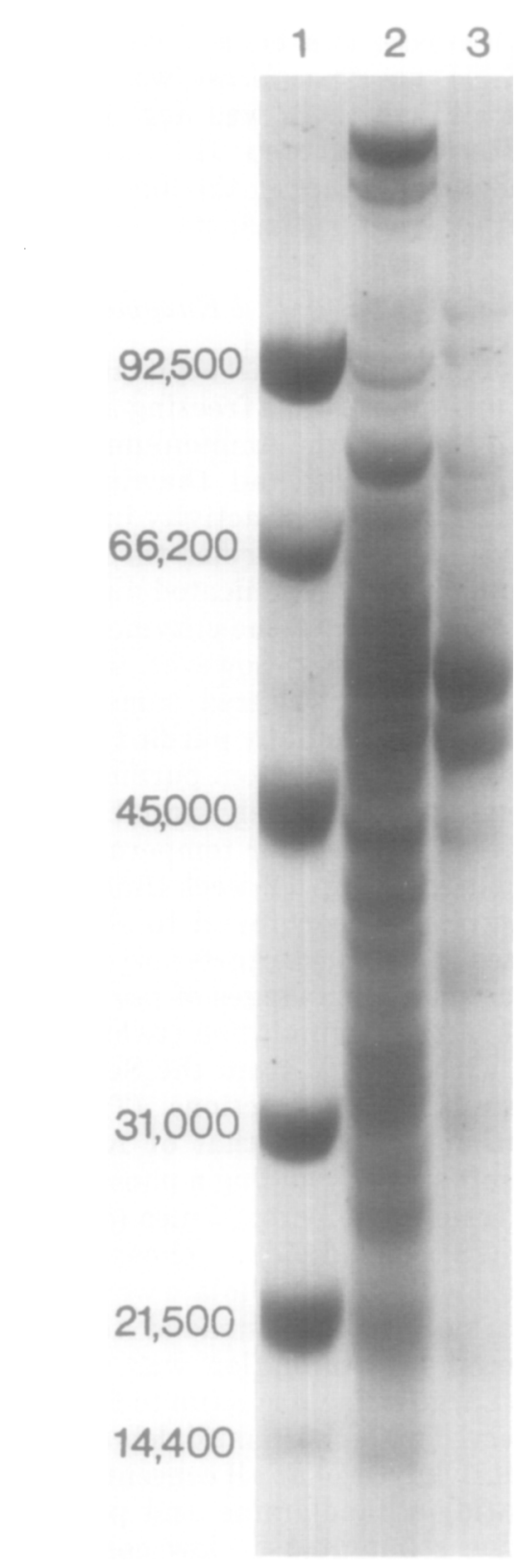

FIG. 2. SDS-polyacrylamide gel electrophoresis of the partially purified DHAP acyltransferase. The electrophoresis was done as described in the text. Lane 1-marker protein standards obtained from BioRad Laboratories. The $M_{\mathrm{r}}$ of the standard proteins are indicated next to the bands. Lane 2-guinea pig liver "light mitochondrial" fraction, i.e., starting material (Table I). Lane 3-enzyme purified through Sepharose $6 \mathrm{~B}$ (fraction B) step. 
two acyltransferases behave very differently. G-3-P acyltransferase was not purified at all, and there was negligible activity after the final step. The recovery of G-3-P acyltransferase in the final enzyme preparation from peroxisomes was $0.03 \%$.

\section{Properties of the Purified Enzyme}

It was found that DHAP acyltransferase became unstable toward freezing after purification through the ammonium sulfate step. Upon freezing and thawing once, there was a $50 \%$ loss of activity in the enzyme which had been purified through the Sepharose 6B step. A sonicated dispersion of Asolectin stabilized the enzyme against freezing and thawing; however, since addition of Asolectin altered some of the properties of the partially purified enzyme, all fractions resulting from purification of the enzyme were routinely stored without Asolectin at refrigerator temperature (2$4^{\circ} \mathrm{C}$ ) and used within a 2 -week time period.

Asolectin has been found to stimulate solubilized DHAP acyltransferase (14). The same was true at all stages of purification with the largest stimulation (twofold) occurring with enzyme from the Sepharose 6B column pooled fractions (Table I). Stimulation similar to that of Asolectin could be obtained by adding a phospholipid extract from crude peroxisomes (data not shown) (28). If individual phospholipids emulsified with sodium cholate were added to the purified enzyme instead of Asolectin, the amount of stimulation was variable (Fig. 3). Large stimulation (up to fourfold) was observed with phosphatidylcholine and phosphatidylglycerol at all concentrations. Phosphatidylethanolamine and phosphatidylserine stimulated at low concentrations $(<1.5 \mathrm{~mm})$ but inhibited at high concentrations. Phosphatidylinositol and phosphatidic acid inhibited at all concentrations (Fig. 3). Asolectin added in the same manner (with sodium cholate) also stimulated the enzyme by two- to threefold (Fig. 3). Sodium cholate itself at the concentration used in the incubation mixture did not affect the enzyme activity.

DHAP acyltransferase in intact peroxi-

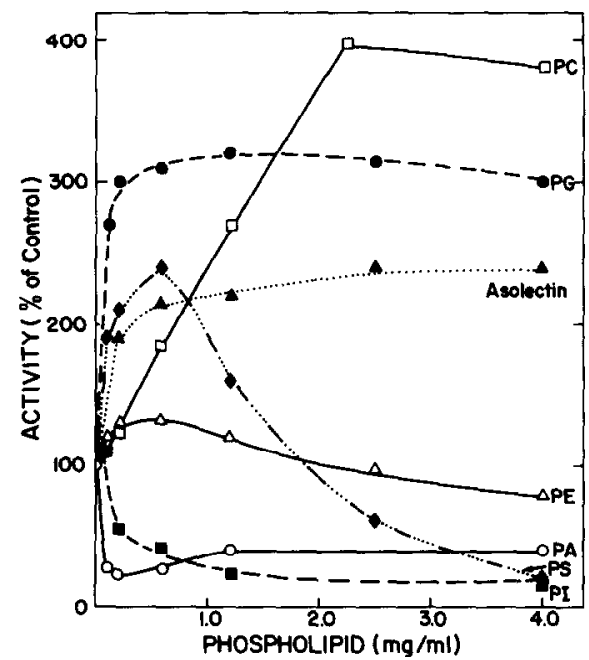

FIG. 3. Stimulation of DHAP acyltransferase activity by different phospholipids. The assay mixture contained Tris-HCl (75 mM, pH 7.4), $\mathrm{MgCl}_{2}$ (4.2 mM), NaF (8.3 mM), palmitoyl CoA $(60 \mu \mathrm{M})$, bovine serum albumin (1 mg), [ ${ }^{32}$ PIDHAP (1-2 $\left.\times 10^{6} \mathrm{cpm}, 0.32 \mathrm{mM}\right)$, different amounts of phospholipid, and Sepharose $6 B$ peak B enzyme (6.5 $\mu \mathrm{g}$ protein) in a total volume of $0.6 \mathrm{mI}$. Each phospholipid mixture, prepared as described under Experimental Procedures was added to the assay mixture followed by sonication. The reaction was then started by addition of enzyme and sonication. The mixture was incubated at $37^{\circ} \mathrm{C}$ for $15 \mathrm{~min}$, and the amount of palmitoyl [ $\left.{ }^{52} \mathrm{P}\right] \mathrm{DHAP}$ formed was determined by solvent extraction under acidic conditions as described before (14). The specific activity of the enzyme in the absence of phospholipid was $106 \mathrm{nmol} / \mathrm{min} / \mathrm{mg}$ protein. Abbreviations used: PC, phosphatidylcholine; PG, phosphatidylglycerol; PE, phosphatidylethanolamine; PA, phosphatidic acid; PS, phosphatidylserine; PI, phosphatidylinositol.

somes has been found to be stable to heat up to $60^{\circ} \mathrm{C}$, while the solubilized enzyme has been found to be heat labile (14). Not surprisingly, partially purified enzyme was found to be unstable above $40^{\circ}$ (Fig. 4A). The addition of Asolectin to the purified enzyme had little effect upon heat stability (Fig. 4A).

The $\mathrm{pH}$ optimum of peroxisomal DHAP acyltransferase has been reported to be shifted from pH 5.5 to a $\mathrm{pH} 7.4$ upon treatment with several detergents (14). A broad $\mathrm{pH}$ optimum of 7.0-8.2 was found for the partially purified enzyme (Fig. 4B). If Aso- 

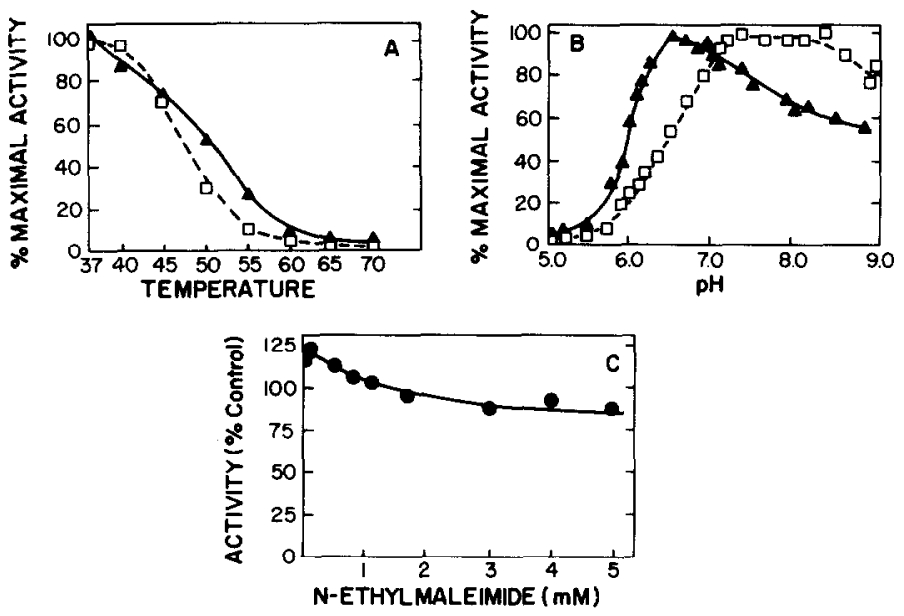

FIG. 4. (A) Thermolahility of partially purified DHAP acyltransferase with (A) and without (П) Asolectin. The purified enzyme (3.14 $\mu \mathrm{g}$ protein) in Tris-HCl buffer $(10 \mathrm{~mm}, \mathrm{pH} 7.4)$ containing dithiothreitol $(1 \mathrm{~mm})$ in the absence or presence of Asolectin liposomes (20 $\mu \mathrm{mol}$ of phospholipid phosphorus) in a total volume of $0.5 \mathrm{ml}$ was heated at different temperatures for $15 \mathrm{~min}$ and then cooled immediately in ice-water. An aliquot of the mixture was used to determine the enzyme activity at $37^{\circ} \mathrm{C}$. The initial specific activity of the enzyme was $201 \mathrm{nmol} / \mathrm{min} / \mathrm{mg}$ with Asolectin and $105 \mathrm{nmol} / \mathrm{min} / \mathrm{mg}$ without Asolectin. (B) The $\mathrm{pH}$ dependence of partially purified DHAP acyltransferase with (closed symbols) and without (open symbols) Asolectin. Different buffers (0.1 $\mathrm{M}$ final concentrations) were used for different $\mathrm{pH}$ as below: acetate buffers for $\mathrm{pH} 4.0-5.25 ; 2-$ morpholinoethanesulfonic acid buffer for $\mathrm{pH}$ 5.0 7.4; Tris-HCl buffer for $\mathrm{pH}$ 7.1-9.1. Results are expressed as percentage of maximum activity, which is $252 \mathrm{nmol} / \mathrm{min} / \mathrm{mg}$ protein for DHAP acyltransferase with Asolectin and $104 \mathrm{nmol} / \mathrm{min} / \mathrm{mg}$ without Asolectin. (C) Effect of $N$-ethylmaleimide on DHAP acyltransferase. Enzyme $(6.28 \mu \mathrm{g})$ in Tris-IICl (10 mM, pII 7.4) and dithiothreitol (1 $\mathrm{mM})$ was preincubated at $37^{\circ}$ for $10 \mathrm{~min}$ with varying concentrations of $N$-ethylmaleimide in a total volume of $0.6 \mathrm{ml}$. Aliquots $(0.1 \mathrm{ml})$ of the reaction mixture were assayed in the presence of Asolectin for DHAP acyltransferase activity as described in the text. The specific activity of DHAP acyltransferase without $N$-ethylmaleimide was $167 \mathrm{nmol} / \mathrm{min} / \mathrm{mg}$ protein.

lectin was added to the enzyme, a shift of $\mathrm{pH}$ optimum to $\mathrm{pH} 6.4$ was observed (Fig. 4B).

The sulfhydryl blocking agent $\mathrm{N}$-ethylmaleimide has been found to stimulate DHAP acyltransferase in intact peroxisomes $(11,14)$. When the partially purified enzyme was treated with $N$-ethylmaleimide, a small (20\%) but reproducible stimulation was also observed (Fig. 4C). However, several other sulfhydryl reagents inhibited the partially purified enzyme. For example, $p$-chloromercuriphenyl sulfonic acid ( $5 \mathrm{~mm}$ ) inhibited the activity by $40-$ $50 \%$; iodoacetamide $(5 \mathrm{~mm})$ inhibited by 515\%; and 5,5'-dithiobis(2-nitrobenzoic acid) (5 mM) inhibited by $20-30 \%$ (28).

Membrane-bound DHAP acyltransfer- ase was found to exhibit a specificity for saturated acyl CoA's (16:0 and 18:0) as substrates with low activity toward mono- and polyunsaturated acyl CoA's (18:1, 18:2, 18:3, $20: 4)(5,10)$. With the partially purified enzyme a similar specificity toward different acyl CoA's was found. For example, highest activity was found with palmitoyl CoA (210 $\mathrm{nmol} / \mathrm{min} / \mathrm{mg}$ protein) followed by a stearoyl CoA ( $35 \%$ to that of palmitoyl $\mathrm{CoA}$ ). With a number of other unsaturated acyl CoA's (18:1, 18:2, 20:4, 22:4 and 22:6) the activity was only $0-6 \%$ of that found with palmitoyl CoA (28).

\section{Kinetics of the Purified Enzyme}

The kinetic properties of partially purified DHAP acyltransferase in the pres- 
ence and in the absence of Asolectin were quite different (Fig. 5). In the absence of Asolectin and with increasing concentrations of DHAP (constant palmitoyl CoA), there was a break in the reciprocal plot at 0.2-0.3 mM DHAP. The $V_{\max }$ at $\mathrm{pH} 7.4$ was $333 \mathrm{nmol} / \mathrm{min} / \mathrm{mg}$ protein with two apparent $K_{m}$ 's of $0.1 \mathrm{~mm}$ (upon extrapolation) and $0.50 \mathrm{mM}$. In the presence of Asolectin, there was no break in the reciprocal plot (Fig. 5), and the $K_{m}$ and $V_{\max }$ were $0.1 \mathrm{~mm}$ and $333 \mathrm{nmol} / \mathrm{min} / \mathrm{mg}$ protein, respectively).

The $K_{m}$ for palmitoyl CoA was difficult to obtain since at higher concentration of palmitoyl CoA the reaction displayed nonMichaelis-Menten kinetics. Another complicating factor was the presence of bovine serum albumin in the incubation mixture, which, by binding to palmitoyl CoA, made the actual free palmitoyl CoA concentration unknown. However, below $50 \mu \mathrm{M}$ palmitoyl CoA, regular Michaelis-Menten ki- netics were observed, and the apparent $K_{m}$ was calculated to be $65 \mu \mathrm{M}(28)$.

\section{Reversibility of the Acyltransferase \\ Reaction}

A CoA-dependent transfer of the acyl group from acyl DHAP to various acceptors has been reported previously, and it has been postulated that the reaction catalyzed by DHAP acyltransferase may be reversible (16). The reversibility is shown here directly by demonstrating the formation of acyl $\left[{ }^{3} \mathrm{H}\right] \mathrm{CoA}$ upon incubation of palmitoyl DHAP with $\left[{ }^{3} \mathrm{H}\right] \mathrm{CoA}$ in the presence of purified enzyme (Table II). The identity of acyl $\left[{ }^{3} \mathrm{H}\right] \mathrm{CoA}$ was confirmed by thin-layer chromatography on silica gel in which the labeled compound migrated with palmitoyl CoA $\left(R_{f}=0.48\right)$ in a solvent system containing n-butanol:acetic acid: $\mathrm{H}_{2} \mathrm{O}$ (5:2:3 v/v) (18). Further evidence for the reversibility the acyltransferase reaction

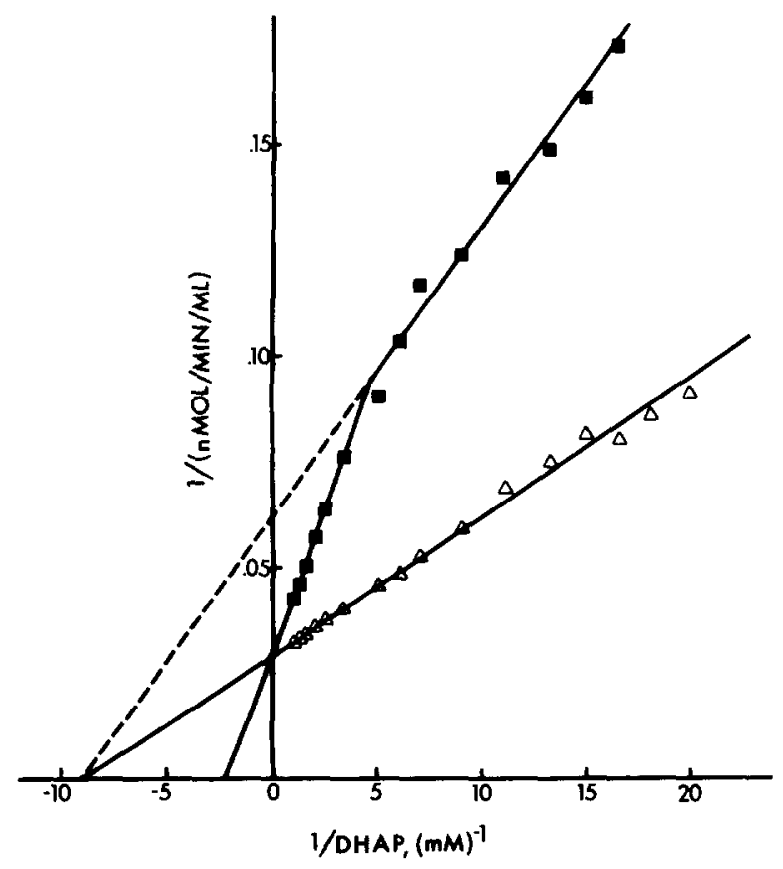

FIG. 5. Activity of DHAP acyltransferase at different DHAP concentrations. Enzyme partially purified through Sepharose $6 \mathrm{~B}$ were assayed as described in the text in the presence of $(\Delta)$ and absence ( $\square$ ) of Asolectin (16.7 $\mu \mathrm{mol}$ phospholipid). Activity (reciprocal plot) was given as $\mathrm{nmol}$ $\mathrm{min} / \mathrm{ml}$ of enzyme. 
TABLE II

Formation of PaLmitorl $\left[{ }^{3} \mathrm{H}\right] \mathrm{CoA}$ From PaLMITOYL DHAP AND $\left[{ }^{3} \mathrm{H}\right] \mathrm{CoA}$

\begin{tabular}{lc}
\hline \multicolumn{1}{c}{ Conditions } & $\mathrm{cpm} \times 10^{-3}$ \\
\hline Whole system, $60 \mathrm{~min}$ & 99 \\
Whole system, $120 \mathrm{~min}$ & 125 \\
$\begin{array}{l}\text { Zero time control } \\
\text { Whole system minus enzyme }\end{array}$ & 0.6 \\
$\begin{array}{l}\text { (60 min) } \\
\text { Whole system minus acyl DHAP } \\
(60 \mathrm{~min})\end{array}$ & 0.4 \\
\hline
\end{tabular}

Note. The reaction mixture (whole system) contained palmitoyl DHAP (50 nmol), NaF (8.3 mM), $\mathrm{MgCl}_{2}$ (4.2 $\left.\mathrm{mM}\right)$, bovine serum albumin (2.0 mg), Asolectin $(0.5 \mathrm{mg})$, glutathione (4.2 $\mathrm{mM}),\left[G{ }^{3} \mathrm{H}\right] \mathrm{CoA}(0.5$ $\left.\mathrm{mM}, 1.2 \times 10^{6} \mathrm{cpm}\right)$, Tris-HCl buffer (75 mM, pH 7.4), and enzyme ( $8 \mu \mathrm{g}$ protein of Sepharose 6B Peak B) in a total volume of $1.2 \mathrm{ml}$. The incubations were done at $37^{\circ} \mathrm{C}$ for the indicated time period and the reactions were stopped by adding $0.2 \mathrm{ml}$ of $10 \% \mathrm{HClO}_{4}$, followed immediately by $0.1 \mathrm{ml}$ of $10 \mathrm{mg} / \mathrm{ml}$ palmitoyl CoA as carrier. The mixture was cooled to $4^{\circ} \mathrm{C}$ and then centrifuged $15 \mathrm{~min}$ at $12,000 \mathrm{~g}$. The precipitate containing palmitoyl $\mathrm{CoA}$ was washed twice with $2 \%$ $\mathrm{HClO}_{4}$ and then with acetone and ether as described before (Ref. (18)). The dry precipitate was then extracted with two $0.5-\mathrm{ml}$ portions of Tris- $\mathrm{HCl}$ buffer $(\mathrm{pH} 7.4)$ and the radioactivity in an aliquot of the extract was determined. Another aliquot was used for thin-layer chromatography to identify palmitoyl $\left[{ }^{3} \mathrm{H}\right] \mathrm{CoA}$ (see text). Controls were also run as indicated below.

a The reaction was stopped immediately after adding the enzyme.

is seen in the enzymatic exchange of acyl group between DHAP and palmitoyl DHAP. This is shown in Table III where radioactive acyl DHAP is found to be formed when [ $\left.{ }^{32} \mathrm{P}\right] \mathrm{DHAP}$ and palmitoyl DHAP are incubated together in the presence of CoA.

\section{DISCUSSION}

Membrane-bound acyltransferases have proven difficult to solubilize and purify and till now only a few of them have been purified to a limited extent $(2,4,29-31)$. In this respect the partially purified DHAP acyltransferase, as reported here, probably represents the most purified mammalian long chain acyltransferase described to date. The enzyme was by no means homogeneous at this stage since, as mentioned before, several bands were seen on sodium dodecyl sulfate gel electrophoresis. The purification achieved was approximately 100 -fold relative to the peroxisomal fraction. It should be pointed out here that since about $60 \%$ of total DHAP acyltransferase activity is latent, the actual increase in specific activity was 40 -fold (Table I). When this latency is taken into account, then, as seen from Table I, the liver DHAP acyltransferase activity $(0.5 \mathrm{nmol} / \mathrm{min} / \mathrm{mg}$ protein) is comparable to that of liver G3-P acyltransferase (mitochondrial plus microsomal) activity $(0.66 \mathrm{nmol} / \mathrm{min} / \mathrm{mg}$ protein).

In guinea pig and rat liver, we found that most $(>90 \%)$ of DHAP acyltransferase was present in the peroxisomal fraction, and its properties were quite different from the G-3-P acyltransferase present in the same fraction $(13,14)$. As reported here, less than $1 \%$ of the G-3-P acyltransferase activity present in the peroxisomal fraction was recovered in the $6 \mathrm{~B}$ pool fraction, with little purification, while $20-30 \%$ of the DHAP acyltransferase activity was recovered with a 100-fold purification. This confirmed our previous hypothesis (14) that peroxisomal DHAP acyltransferase is highly specific for DHAP, with very little activity toward G-3-P as a substrate.

The purified enzyme is stimulated by Asolectin and other phospholipids. Asolectin has been shown to contain phosphatidylcholine, phosphatidylethanolamine, and phosphatidylinositol (32). Among these lipids, phosphatidylcholine and phosphatidylethanolamine (at low concentration) stimulated the enzyme (Fig. 3 ). Use of Asolectin and other phospholipids is becoming a very common method to stabilize and stimulate membrane-bound enzymes $(19,30,32)$. Apparently, phospholipids are an integral part of many membrane-bound enzymes and are necessary for the maintenance and expression of enzyme activity. This specific interaction between membrane-bound enzymeprotein and membrane lipids has been exten- 
sively studied by Fleischer and co-workers $(33,34)$.

Many of the properties of the partially purified DHAP acyltransferase were different from those for the enzyme from intact peroxisomes. DHAP acyltransferase from intact peroxisomes was stimulated with $\mathrm{Mg}^{2+}, \mathrm{Mn}^{2+}$, and $\mathrm{Ca}^{2+}$, but these divalent cations did not stimulate the partially purified enzyme (28). $\mathrm{Mg}^{2+}$ and other ions probably act to protect the product acyl DHAP by inhibiting lipid phosphomonoesterase present in the crude membrane fraction (5); however, during the purification of the acyltransferase lipid phosphomonoesterase was removed (Jones and Hajra, unpublished results). $\mathrm{Cu}^{2+}$ and $\mathrm{Cd}^{2+}$ inhibited (80-90\%) partially purified DHAP acyltransferase (28) as well as enzyme from intact peroxisomes (14) but the extent of inhibition was greater for the partially purified enzyme. Since $\mathrm{Cu}^{2+}$ and $\mathrm{Cd}^{2+}$ are sulfhydryl-blocking reagents, sulfhydryl groups may be involved in maintaining the activity of DHAP acyltransferase. This view is reinforced by the fact that enzyme activity during storage is protected by dithiothreitol. However, inhibition of DHAP acyltransferase by $\mathrm{Cu}^{2+}$ and $\mathrm{Cd}^{2+}$ as well as by other sulfhydryl reagents, including $p$-chloromercuriphenyl sulfonic acid, iodoacetamide, and 5,5'-dithiobis(2-nitrobenzoic acid), is incomplete. Therefore, the sulfhydryl groups which are blocked by these reagents may not be crucial for the reactivity of the enzyme. The purified enzyme also differed from the membrane-bound form in being less stable toward heat even in the presence of Asolectin (Fig. 4A). The $\mathrm{pH}$ optimum of the purified enzyme (pH 7.0-8.2 optimum range) was different from the peroxisomal membrane-bound form ( $\mathrm{pH}$ 5.5). As previously shown this shift to higher $\mathrm{pH}$ optimum occurred when the enzyme was solubilized from membrane with different detergents (14). The shift may result from a change to a less hydrophobic microenvironment of the enzyme upon its solubilization from the peroxisomal membrane. When the microenvironment of the purified enzyme was made more hydrophobic by addition of a phospholipid dispersion (Asolectin), the $\mathrm{pH}$ optimum was shifted to an intermediate value ( $\mathrm{pH}$ 6.4) (Fig. 4B).

The addition of Asolectin affected the kinetic properties of DHAP acyltransferase. In the absence of Asolectin, the Lineweaver-Burk plots, as shown in Fig. 5, were biphasic and the two $K_{m}$ values were 0.1 and $0.5 \mathrm{~mm}$. However, monophasic kinetics were observed for the purified enzyme when it was assayed in the presence of Asolectin, and the single $K_{m}$ obtained was $0.1 \mathrm{~mm}$ (Fig. 5). A probable explanation of this finding is that there are two populations of enzyme, one (lower $K_{m}$ ) which is still associated with endogenous phospholipid and another which is not. After addition of phospholipids to the purified enzyme, all of the enzyme molecules become associated with lipid and monophasic kinetics are observed.

The acylation of DHAP, catalyzed by DHAP acyltransferase, appears to be reversible in nature. With membrane-bound enzyme it was postulated that the reaction is reversible since labeled DHAP was found to be rapidly exchanged with acyl DHAP in the presence of $\mathrm{CoA}(16)$. This exchange reaction is also seen with the partially purified enzyme (Table III) which is completely dependent on the presence of CoA. The reverse reaction is directly demon-

\section{TABLE III}

Enzymatic Exchange of Palmitoyl DHAP AND DHAP

\begin{tabular}{lc}
\hline \multicolumn{1}{c}{ System } & $\begin{array}{c}\text { Radioactivity in lipid } \\
\left(\mathrm{cpm} \times 10^{-8}\right)\end{array}$ \\
\hline (A) Whole system & 15.0 \\
(B) Whole system, minus CoA & 0.4 \\
(C) Whole system, minus & \\
palmitoyl DHAP & 0.3 \\
(D) Whole system, 0 time & 0.4 \\
\hline
\end{tabular}

Note. The whole system contained Tris- $\mathrm{HCl}$ buffer ( $75 \mathrm{mM}$, $\mathrm{pH}$ 7.5), $\mathrm{NaF}$ (8.3 mM), $\mathrm{MgCl}_{2}$ (4.2 mM), $\mathrm{CoA}(50 \mu \mathrm{M})$, palmitoyl DHAP (0.2 mM), [ ${ }^{22}$ PJDHAP $\left(0.25 \mathrm{mM}, 4 \times 10^{6} \mathrm{cpm}\right)$, Asolectin $(1 \mathrm{mg})$, and partially purified enzyme (6.5 $\mu \mathrm{g}$ protein). The mixture was incubated at $37^{\circ} \mathrm{C}$ for $16 \mathrm{~min}$ and the palmitoyl $\left[{ }^{32} \mathrm{P}\right] \mathrm{DHAP}$ was extracted, washed to remove [ $\left.{ }^{22} \mathrm{P}\right] \mathrm{DHAP}(10$, 16) and the radioactivity of an aliquot of the lipid extract was determined. 
strated by measuring the conversion of $\left[{ }^{3} \mathrm{H}\right] \mathrm{CoA}$ to palmitoyl $\left[{ }^{3} \mathrm{H}\right] \mathrm{CoA}$ in the presence of palmitoyl DHAP (Table II). The rate of conversion of $\left[{ }^{3} \mathrm{H}\right] \mathrm{CoA}$ to palmitoyl $\left[{ }^{3} \mathrm{H}\right] \mathrm{CoA}$ slowed considerably after $2 \mathrm{~h}$, and after $3 \mathrm{~h}$ there was $11.1 \%$ total conversion of $\left[{ }^{3} \mathrm{H}\right] \mathrm{CoA}$ to palmitoyl $\left[{ }^{3} \mathrm{H}\right] \mathrm{CoA}$. No attempt was made to calculate an equilibrium constant for the reaction since both micellar and monomeric forms of acyl $\mathrm{CoA}$ and acyl DHAP are present in the reaction mixture and bovine serum albumin, which was present in the incubation mixture, binds both the substrate acyl DHAP and the product $\left[{ }^{3} \mathrm{H}\right]$ acyl $\mathrm{CoA}$. These results show, however, that the reaction is definitely reversible, which has not yet been demonstrated for the comparable enzyme, G-3-P acyltransferase. This indicates that the ester bond in acyl DHAP may have a higher free energy of hydrolysis than the $\mathrm{O}$-ester bonds in glycerolipids. Further work on the purification of the enzyme to homogeneity and its specific role in cellular lipid biosynthesis are in progress in our laboratory.

\section{REFERENCES}

1. HaJRA, A. K. (1977) Biochem. Soc. Trans. 5, 3436.

2. VAN DEN Bosch, H. (1974) Ann. Rev. Biochem. 43, 243-277.

3. WYKLE, R. L., AND SNYDER, F. (1976) in "The Enzymes of Biological Membranes" (A. Martinossi, ed.), Vol. 2, pp. 87-117, Plenum, New York.

4. Bell, R. M., and Coleman, R. A. (1980) Ann. Rev. Biochem. 49, 459-487.

5. HAJRA, A. K. (1968) J. Biol. Chem. 243, 34-65.

6. LaBelle, E. F., JR., and HaJRA, A. K. (1972) J. Biol. Chem. 247, 5835-5841.

7. RAO, G. A., SorRels, M. F., AND REISER, R. (1970) Lipids 5, 762-764.

8. SchLossman, D. M., AND BeLl, R. M. (1977) Arch. Biochem. Biophys. 182, 732-742.

9. Rock, C. O., FitzgeraLd, V., AND SNYDER, F. (1977) J. Biol. Chem. 252, 6363-6366.

10. HajRA, A. K., AND Burke, C. L. (1978) J. Neurochern. 31, 125-134.

11. BATES, E. J., AND SAggerson, E. D. (1979) Biochem. J. 182, 751-762.
12. JONES, C. L., AND HAJRA, A. K. (1977) Biochem. Biophys. Res. Commun. 76, 1138-1143.

13. HaJRA, A. K., BURKE, C. L., AND JoNES, C. L. (1979) $J$. Biol Chem. 254, 10,896-10,900.

14. Jones, C. L., AND HaJra, A. K. (1980) J. Biol. Chem. 255, 8289-8295.

15. Schlossman, D., AND Bell, R. M. (1976) J. Biol. Chem. 251, 5738-5744.

16. HaJRA, A. K. (1974) Biochem. Biophys. Res. Commun. 57, 668-674.

17. HAJRA, A. K., AND AgranOFF, B. W. (1968) J. Biol. Chem. 243, 1617-1622.

18. Bishop, J. E., AND HaJRA, A. K. (1980) Anal. Biochem. 106, 344-350.

19. Monroy, G., Kelker, H., AND Pulluman, M. (1973) J. Biol Chem 248, 2845-2852.

20. AMES, B. N., AND Dubin, D. T. (1960) J. Biol Chem. 235, 769-775.

21. Lowry, O. H., Rosebrough, N. J., FARr, A. L., AND RANDALL, R. J. (1951) J. Biol. Chem. 193, 265-275.

22. Bensadoun, A., AND Weinstein, D. (1976) Anal Biochem. 70, 241-250.

23. Fairbanks, G., Steck, T. L., and Wallach, D. F. H. (1971) Biochemistry 10, 2606-2616.

24. LaBelle, E. F., JR., AND HaJRA, A. K. (1972) $J$. Biol. Chem. 247, 5825-5834.

25. De Duve, C., Pressman, B. C., Gianetto, R., WatTIAUX, R., AND APPELMANS, F. (1955) Biochem. J. 60, 604-607.

26. Shaltiel, S. (1974) in "Methods in Enzymology" (W. B. Jakoby and M. Wilchek, eds.), Vol. 34, pp. 126-140, Academic Press, New York.

27. Chibata, I., Tosa, T., AND Matco, Y. (1974) in "Methods in Enzymology" (W. B. Jakoby and M. Wilchek, eds.), Vol. 34, pp. 267-272, Academic Press, New York.

28. Jones, C. L. (1979) Ph.D. Dissertation, University of Michigan.

29. YamashitA, S., AND NUMA, S. (1972) Eur. J. Biochem. 31, 565-573.

30. Takenawa, T., and Egawa, K. (1977) J. Biol Chem. 252, 5419-5423.

31. Hasegawa-SaSaKi, H., AND OhNo, K. (1980) Biochim. Biophys. Acta 711, 357-360.

32. MILleR, C., AND RACKER, E. (1976) J. Membr. Biol. 26, 319-333.

33. Gazzotti, P., Bock, H., AND Fleischer, S. (1975) J. Biol. Chem. 250, 5782-5790.

34. Isaacson, Y., Deroo, P. W., Rosenthal, A. F., BitTman, R., McInTYRe, J. O., Bock, H., GazzotTI, P., AND Fleischer, S. (1979) J. Biol. Chem. 254, 117-126. 